\title{
ELMO1 wt Allele
}

National Cancer Institute

\section{Source}

National Cancer Institute. ELMO1 wt Allele. NCI Thesaurus. Code C94805.

Human ELMO1 wild-type allele is located in the vicinity of 7p14.1 and is approximately 595 $\mathrm{kb}$ in length. This allele, which encodes engulfment and cell motility protein 1, plays a role in signal transduction, phagocytosis, apoptosis and cytoskeletal rearrangement. 